\title{
Jackfruit (Artocarpus heterophyllus), a new host plant of Ceratocystis wilt in South Sumatra, Indonesia
}

\author{
Rahmat Pratama ${ }^{1} \cdot$ Ahmad Muslim² $^{2} \cdot$ Suwandi Suwandi ${ }^{2} \cdot$ Nurhayati Damiri $^{2} \cdot$ Soleha Soleha $^{1}$
}

Received: 22 February 2021 / Accepted: 4 August 2021 / Published online: 11 September 2021

(c) Australasian Plant Pathology Society Inc. 2021

\begin{abstract}
In 2019, wilt and sudden death were observed on Artocarpus heterophyllus (jackfruit). Identification was performed by sequence analysis of the concatenated $\beta$-tubulin and ITS gene regions. Sequencing of the PCR product confirmed this pathogen was Ceratocystis fimbriata sensu stricto. This is the first report of $C$. fimbriata causing sudden death disease in $A$. heterophyllus in Indonesia and worldwide.
\end{abstract}

Keywords Sudden death disease $\cdot$ Moraceae $\cdot$ Ceratocystis fimbriata sensu stricto

Jackfruit (Artocarpus heterophyllus, Moraceae) is known in Indonesian as "Nangka", and is cultivated widely in many countries with tropical and subtropical climates. Jackfruit is among the most exported fruits worldwide and has considerable nutrition and health benefits (Ranasinghe et al. 2019).

In July 2019, wilt and die-back symptoms were observed for the first time on A. heterophyllus in the agricultural field of Sriwijaya University (Indralaya), Plaju (Palembang) and Gelumbang (Prabumulih), Indonesia. Wood of wilted trees showed a brown to black streaking in the woody xylem. Symptoms on the dying Jackfruit wood produced grey to brown lesions and included a streaking pattern of discoloration in the sapwood (Fig. 1a) and in some cases the lesions extended to heartwood (Fig. 1b). The lesion could be found partially or totally affecting the sapwood from the basal stem to the branches. Leaves of dying trees had yellowing symptoms, followed by wilting of the leaves on several lateral branches, drying of twigs and the wilt of the whole tree (Fig. 1c). This type of wilting was termed as sudden death or wilt (Pratama et al. 2021).

Ahmad Muslim

a_muslim@unsri.ac.id

1 Agriculture Sciences Graduate Program, Faculty of Agriculture, Universitas Sriwijaya, Jl. Padang Selasa No. 524, Bukit Besar, Palembang, South Sumatra 30139, Indonesia

2 Laboratory of Phytopathology, Department of Plant Protection, Faculty of Agriculture, Sriwijaya University, Indralaya, South Sumatera 30662, Indonesia
Wood samples were taken from lesions of wilted trees using a knife sterilised in 70\% ethanol. Each sample was wrapped in tissue paper and placed in a cool box. The same day, the wood samples (1-20 mm length, 1-2 mm thick) were sandwiched between two slices of fresh carrot and placed on sterile dry paper in plastic boxes at $25^{\circ} \mathrm{C}$ following the method of Moller and DeVay (1968) (Fig. 1d). After 5-10 days, hat-shaped spores of putative Ceratocystis pathogens were placed on $2 \%(\mathrm{w} / \mathrm{v})$ malt extract agar (MEA) (Merck, Germany), and incubated at $25{ }^{\circ} \mathrm{C}$ in a laboratory. The isolated fungi were initially identified based on morphological characteristics of a 14 day old culture. Mycelium on MEA grey, reverse side of colony olivaceous grey; submerged mycelium darkening as the ascomata develop forming fine, radiating fibrils.

Morphological traits of fruiting bodies and spores were observed under an optical Olympus CX33 microscope. Ascomatal bases dark brown to black, base subglobose to globose and measured $(\mathrm{n}=100), 131.5-250.7 \times 101.6-236.5 \mu \mathrm{m}$ (Fig. 2a). Ascomata necks erect, occasionally curved, black at the base becoming subhyaline towards the apex, smooth to crenulate, 324.7-579.1 $\mu \mathrm{m}$ long including ostiolar hyphae (Fig. 2b). Phialides pale brown to hyaline (Fig. 2c). Ascospores hat-shaped, 3.4-6.8 $\times 2.1-6.2 \mu \mathrm{m}$ (Fig. 2d). Bacilliform conidia 11.1-36.1 $\times 2.1-7.4 \mu \mathrm{m}$ (Fig. 2e). Barrel conidia 4.4-16.1 $\times 2.7-6.9 \mu \mathrm{m}$ (Fig. $2 \mathrm{f}$ ). Chlamydospores oval, thick walled, smooth, 6.7-16.5 $\times 5.9-12.9 \mu \mathrm{m}$ (Fig. 2g). Based on these morphological characters, the fungus was identified as Ceratocystis fimbriata. Two representative isolates were deposited at the ICBB Culture Collection 
Fig. 1 Symptoms of Ceratocystis fimbriata wilt disease in Artocarpus heterophyllus: a vascular discoloration of infected tree; $\mathbf{b}$ the discolored wood extended to the heartwood of the basal stem; $\mathbf{c}$ three-yearold tree with wilted, yellowing leaves and rotten fruit; $\mathbf{d}$ isolation of the fungus from discoloured xylem showing dark mycelium and sporulation on the carrot slices after 7 days

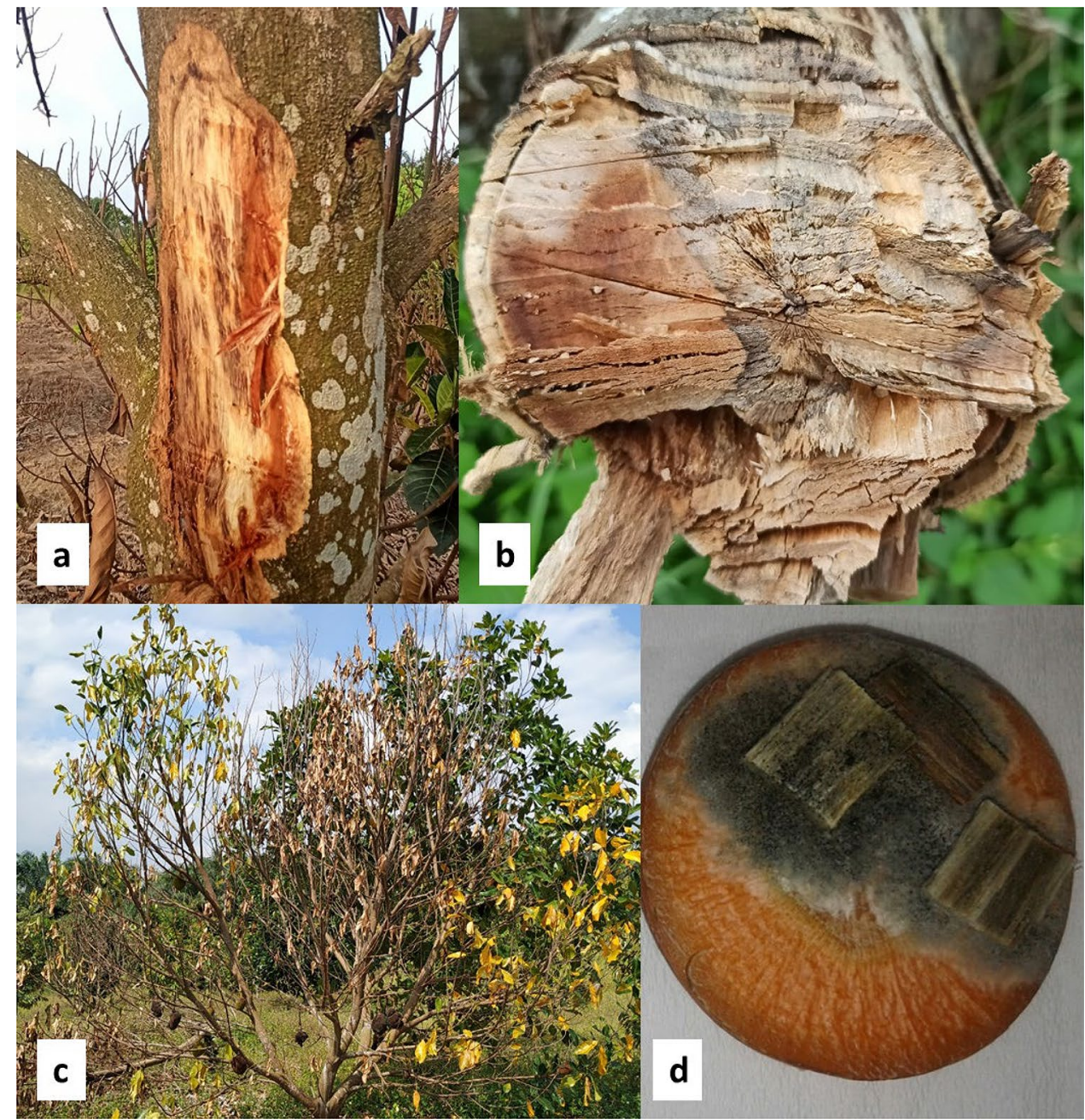

for Microorganisms and Cell Culture, Indonesian Center for Biodiversity and Biotechnology, (Bogor, Indonesia) as accessions ICBB9852 and ICBB9853.

To confirm the species identification, isolates were cultured on potato dextrose broth (PDB) at room temperature for one week. Mycelium was filtered through Whatman filter paper and genomic DNA was extracted from the fungal mycelial mat using YeaStar Genomic DNA Kit (Zymo Research Corporation, California, USA). PCR conditions and reactions for two gene regions were used to identify the Ceratocystis isolates; the Internal Transcribed Spacer (ITS) with primers ITS 1 and ITS4 (White et al. 1990) and part of the $\beta$-tubulin ( $\beta \mathrm{t}$ ) gene with primers $\beta \mathrm{t} 1 \mathrm{a}$ and $\beta \mathrm{t} 1 \mathrm{~b}$ (Glass and Donaldson 1995). Amplifications were carried out in $50 \mu \mathrm{l}$ reactions containing $20 \mu \mathrm{l}$ DreamTaq Green PCR Master Mix (Eppendorf, Germany) (DreamTaq DNA Polymerase, 2X DreamTaq Green buffer, dNTPs, and $4 \mathrm{mM}$ $\mathrm{MgCl}_{2}$ ), $1.5 \mu \mathrm{l}$ of each forward and reverse primer, $4 \mu \mathrm{l}$ of DNA template and $23 \mu \mathrm{l}$ sterilised water. The PCRs were performed with a C1000 Touch ${ }^{\mathrm{TM}}$ thermal cycler (Bio-Rad, USA). The PCR cycling parameters were as follows: initial denaturation for $5 \mathrm{~min}$ at $95{ }^{\circ} \mathrm{C}$, followed by 35 cycles at $95{ }^{\circ} \mathrm{C}$ for $30 \mathrm{~s}, 56{ }^{\circ} \mathrm{C}$ for $45 \mathrm{~s}$ and $72{ }^{\circ} \mathrm{C}$ for $1 \mathrm{~min}$. Amplification was completed at $72{ }^{\circ} \mathrm{C}$ for $10 \mathrm{~min}$ and the PCR product was stored at $10^{\circ} \mathrm{C}$. The PCR amplicons were sequenced at 1st BASE (Malaysia).

For the ITS and $\beta$-tubulin, amplification resulted in fragments of $\sim 550$ base pairs (bp) in size. The sequences of the amplified products were then deposited in the GenBank database and assigned accession numbers isolate ICBB9852 (MT355410; MT412106), isolate ICBB9853 (MT355412; MT412108), and isolate CAAW30817 (MT355413, MT412109) for the ITS and $\beta$-tubulin. $\beta$-tubulin datasets were generated using ex-type and ex-paratype sequences representing species in the Latin American (LAC) and Asian clade (AC) (Table 1) of the $C$. fimbriata species complex (Fourie et al. 2015; Oliveira et al. 2015; Barnes et al. 2018). To determine relatedness of isolates from jackfruit with known $C$. fimbriata populations, the ITS sequence was manually aligned with known ITS haplotypes as designated by Harrington et al. (2014), Li et al. (2016) and phylogenetic analyses were performed. Maximum Parsimony 
Table 1 Ceratocystis isolates included in the phylogenetic analyses

\begin{tabular}{|c|c|c|c|c|c|c|}
\hline \multirow[t]{2}{*}{ Species } & \multirow[t]{2}{*}{ Haplotype } & \multirow[t]{2}{*}{ Isolates no } & \multirow[t]{2}{*}{ Host } & \multirow[t]{2}{*}{ Origin } & \multicolumn{2}{|c|}{ GenBank accession no } \\
\hline & & & & & ITS & $\beta$-Tubulin \\
\hline \multirow[t]{37}{*}{ C. fimbriata } & ITS1a & C1418 & Ipomoea batatas & USA & AY157956 & - \\
\hline & ITS1 & $\mathrm{C} 1857$ & Ficus carica & Brazil & HQ157542 & - \\
\hline & ITS1b & CMW4797 & Eucalyptus sp. & Congo & FJ236733 & - \\
\hline & ITSb & CMW9998 & Eucalyptus sp. & South Africa & FJ236721 & - \\
\hline & ITS2 & $\mathrm{C} 1655$ & Mangifera indica & Brazil & HQ157546 & - \\
\hline & ITS3 & $\mathrm{C} 1440$ & Eucalyptus sp. & Brazil & HQ157544 & - \\
\hline & ITS3 & CMW5328 & E. grandis & Uganda & AF395686 & - \\
\hline & ITS4 & $\mathrm{C} 1442$ & Eucalyptus sp. & Brazil & HQ157545 & - \\
\hline & ITS5 & ICBB9852 & Artocarpus heterophyllus & Indonesia & MT355410 & MT412106 \\
\hline & ITS5 & ICBB9853 & A. heterophyllus & Indonesia & MT355412 & MT412108 \\
\hline & ITS5 & CAAW30817 & A. heterophyllus & Indonesia & MT355413 & MT412109 \\
\hline & ITS5 & CMW38737 & E. grandis & Zimbabwe & KF878326 & KF878335 \\
\hline & ITS5 & $\mathrm{C} 1345$ & Eucalyptus sp. & Brazil & AY157966 & - \\
\hline & ITS5 & A59662 & Camellia sinensis & China & KF650948 & - \\
\hline & ITS5 & YM061 & Colocasia esculenta & China & AM712445 & - \\
\hline & ITS5 & P20053 & Punica granatum & China & AM292204 & - \\
\hline & ITS5 & $\mathrm{C} 1$ & Acacia sp. & Vietnam & MF033455 & MF040712 \\
\hline & ITS5 & CMW22563 & A. mangium & Indonesia & EU588656 & EU588636 \\
\hline & ITS5 & WRC & Lansium domesticum & Indonesia & MT229127 & MW013766 \\
\hline & ITS6 & $\mathrm{C} 2055$ & Mangifera sp. & Brazil & HQ157548 & - \\
\hline & ITS6z & CMW13582 & Hypocryphalus mangifera & Oman & KC261853 & - \\
\hline & ITS6z & WBC & L. domesticum & Indonesia & MT229128 & MW013767 \\
\hline & ITS7b & CMW13851 & M. indica & Oman & AY953383 & EF433308 \\
\hline & ITS7b & CMW23634 & M. indica & Pakistan & EF433302 & EF433311 \\
\hline & ITS7b & CMW22579 & A. mangium & Indonesia & EU588658 & - \\
\hline & ITS8a & CMW8856 & Citrus sp. & Colombia & AY233867 & - \\
\hline & ITS8c & CMW17808 & Eucalyptus sp. & Colombia & EF127990 & - \\
\hline & ITS8e & CMW22092 & E. deglupta & Ecuador & FJ151432 & - \\
\hline & ITS9 & $\mathrm{C} 1558$ & M. indica & Brazil & AY157965 & - \\
\hline & ITS9 & C1914 & C. esculenta & Brazil & HQ157540 & - \\
\hline & ITS10 & C994 & M. indica & Brazil & AY157964 & - \\
\hline & ITS10a & Cf4 & M. indica & Brazil & EF042605 & - \\
\hline & ITS11 & C1865 & C. esculenta & Brazil & AY526286 & - \\
\hline & ITS12 & C1926 & C. esculenta & Brazil & HQ157541 & - \\
\hline & ITS14 & C1688 & M. indica & Brazil & AY526291 & - \\
\hline & ITS15 & C925 & Gmelina arborea & Brazil & AY157967 & - \\
\hline & ITS16 & C924 & G. arborea & Brazil & HQ157539 & - \\
\hline \multirow[t]{2}{*}{ C. pirilliformis } & Asian clade (AC) & CMW6569 & E. nitens & Australia & - & DQ371652 \\
\hline & $\mathrm{AC}$ & CMW6579 & E. nitens & Australia & - & DQ371653 \\
\hline \multirow[t]{2}{*}{ C. polychroma } & $\mathrm{AC}$ & CMW11424 & Syzygium aromaticum & Indonesia & - & AY528966 \\
\hline & $\mathrm{AC}$ & CMW11436 & S. aromaticum & Indonesia & - & AY528967 \\
\hline \multirow[t]{2}{*}{ C. atrox } & $\mathrm{AC}$ & CMW19383 & E. grandis & Australia & - & EF070430 \\
\hline & $\mathrm{AC}$ & CMW19385 & E. grandis & Australia & - & EF070431 \\
\hline \multirow[t]{2}{*}{ C. neglecta } & Latin American clade (LAC) & CMW17808 & E. grandis & Colombia & - & EU881898 \\
\hline & LAC & CMW18194 & E. grandis & Colombia & - & EU881899 \\
\hline \multirow[t]{2}{*}{ C. colombiana } & LAC & CMW5751 & Coffea arabica & Colombia & - & AY177225 \\
\hline & LAC & CMW5761 & C. arabica & Colombia & - & AY177224 \\
\hline C. cacaofunesta & $\mathrm{LAC}$ & CMW14803 & Theobroma cacao & Ecuador & - & KJ631108 \\
\hline
\end{tabular}


Table 1 (continued)

\begin{tabular}{|c|c|c|c|c|c|c|}
\hline \multirow[t]{2}{*}{ Species } & \multirow[t]{2}{*}{ Haplotype } & \multirow[t]{2}{*}{ Isolates no } & \multirow[t]{2}{*}{ Host } & \multirow[t]{2}{*}{ Origin } & \multicolumn{2}{|c|}{ GenBank accession no } \\
\hline & & & & & ITS & $\beta$-Tubulin \\
\hline & LAC & CMW15051 & T. cacao & Costa Rica & - & KJ601510 \\
\hline \multirow[t]{2}{*}{ C. papillata } & LAC & CMW8850 & Citrus $\times$ Tangelo hybrid & Colombia & - & AY233875 \\
\hline & LAC & CMW8856 & Citrus limon & Colombia & - & AY233874 \\
\hline \multirow[t]{4}{*}{ C. fimbriata } & LAC & CMW14797 & M. indica & Brazil & - & EF433307 \\
\hline & LAC & CMW28907 & M. indica & Brazil & - & FJ200270 \\
\hline & LAC & CMW1547 & I. batatas & Papua New Guinea & - & EF070443 \\
\hline & LAC & $\mathrm{C} 1421$ & I. batatas & USA & - & KF302689 \\
\hline \multirow[t]{2}{*}{ C. fimbriatomima } & LAC & CMW24174 & Eucalyptus hybrid & Venezuela & - & EF190951 \\
\hline & LAC & CMW24176 & Eucalyptus hybrid & Venezuela & - & EF190952 \\
\hline \multirow[t]{4}{*}{ C. fimbriata } & LAC & CMW21127 & A. crassicarpa & Indonesia & - & EU588643 \\
\hline & LAC & CMW24664 & Eucalyptus hybrid & China & - & JQ862720 \\
\hline & LAC & CBS115173 & Gmelina arborea & Brazil & - & KF302700 \\
\hline & LAC & CBS14653 & C. arabica & Suriname & - & KF302702 \\
\hline \multirow[t]{2}{*}{ C. platani } & LAC & CMW14802 & Platanus occidentalis & USA & - & EF070425 \\
\hline & LAC & CMW23450 & P. occidentalis & Greece & - & KJ601513 \\
\hline
\end{tabular}

Isolates from jackfruit in Indonesia are marked in bold

Fig. 2 Morphological characteristics of Ceratocystis fimbriata isolated from Artocarpus heterophyllus stem lesion: a ascomata with pirilliform base, b divergent ostiolar hyphae; c conidiophore/phialide; $\mathbf{d}$ hat-shaped ascospores; $\mathbf{e}$ cylindrical conidia; $\mathbf{f}$ Chain of barrel-shaped conidia; $\mathbf{g}$ chlamydospores of various shapes. Scale bars: $\mathrm{a}=100 \mu \mathrm{m}$; $\mathrm{b}-\mathrm{c}$, $\mathrm{e}-\mathrm{g}=10 \mu \mathrm{m} ; \mathrm{d}=5 \mu \mathrm{m}$

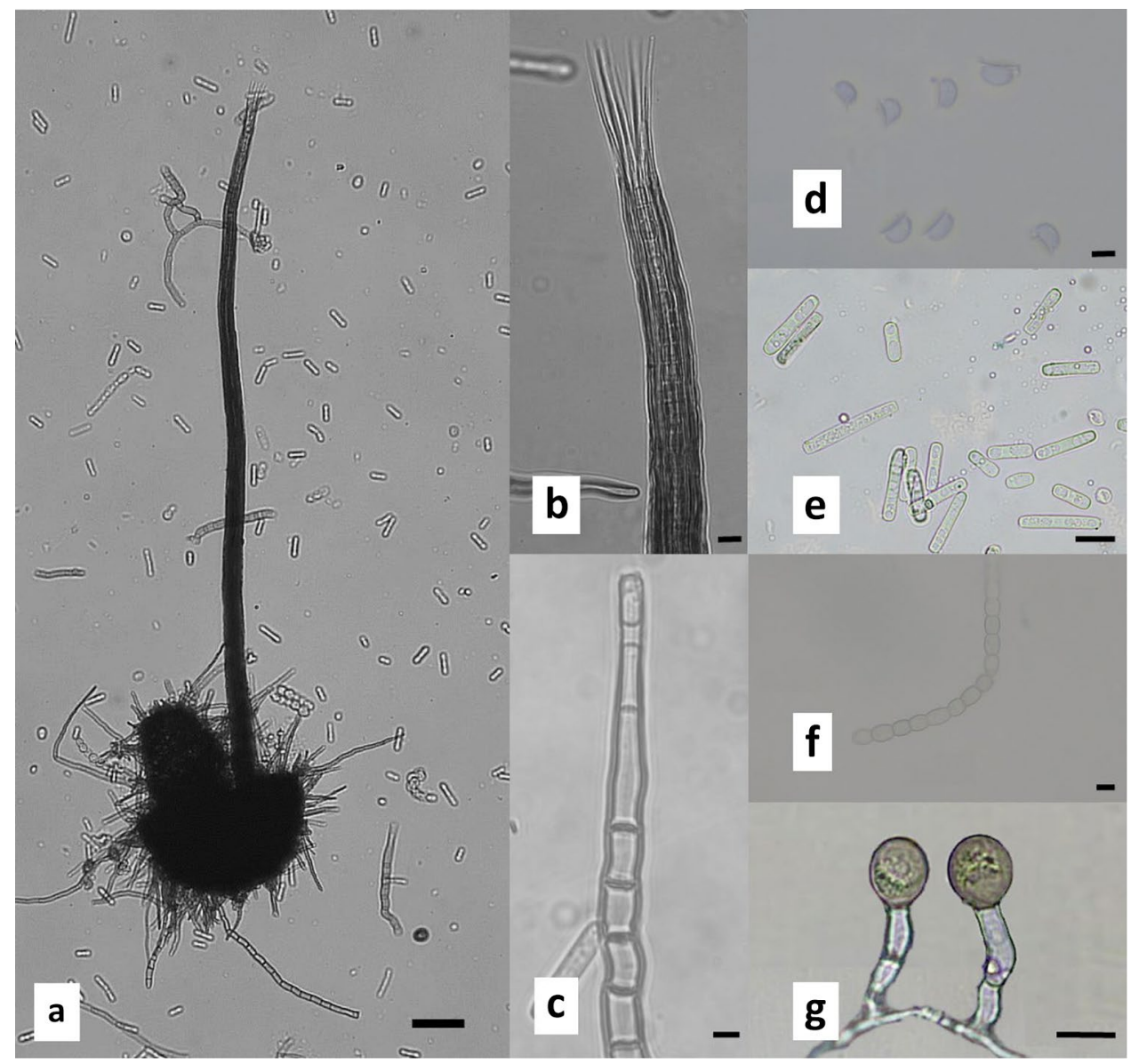

(MP) analyses were performed in MEGA v. 10 (Kumar et al. 2016; Paul et al. 2018) with 1000 replications. The analysis involved 38 ( $\beta$-tubulin) and 37 (ITS) nucleotide sequences. All positions containing gaps and missing data were eliminated. There were 408 ( $\beta$-tubulin) and 518 (ITS) positions in the final dataset. Ceratocystis variospora was 
used as the out-group. $\beta$-tubulin sequence of our isolates confirmed the assignment to LAC of $C$. fimbriata sensu lato (Fig. 3a). Manual alignment of the ITS sequences with previously described ITS genotypes (Harrington et al. 2014; Li et al. 2016) grouped the isolates into ITS5 haplotype of $C$. fimbriata sensu stricto (Fig. 3b). Consistency (CI), retention (RI), and composite indexes (CoI) for $\beta$-tubulin were $0.566667,0.845238,0.668011$, respectively and ITS was $0.933333,0.976563,0.932836$, respectively.

The pathogenic potential of isolates was evaluated by the under bark inoculation method described by O'Gara et al. (1997) using five-month-old A. heterophyllus seedlings with stem diameters of $6-8 \mathrm{~mm}$ and heights $<1.5 \mathrm{~m}$ were prepared for pathogenicity test. Seedlings were grown in $10 \mathrm{~cm}$ diameter plastic pots containing a soil mix (topsoil + peat + chicken manure) under a 50\% shading net. Plants were watered daily to maintain humidity, and any mortality occurring before the end of the experiment was recorded. Wounds were made on the stems of the seedlings using a cork borer ( $4 \mathrm{~mm}$ diam.), and mycelial discs (4 $\mathrm{mm}$

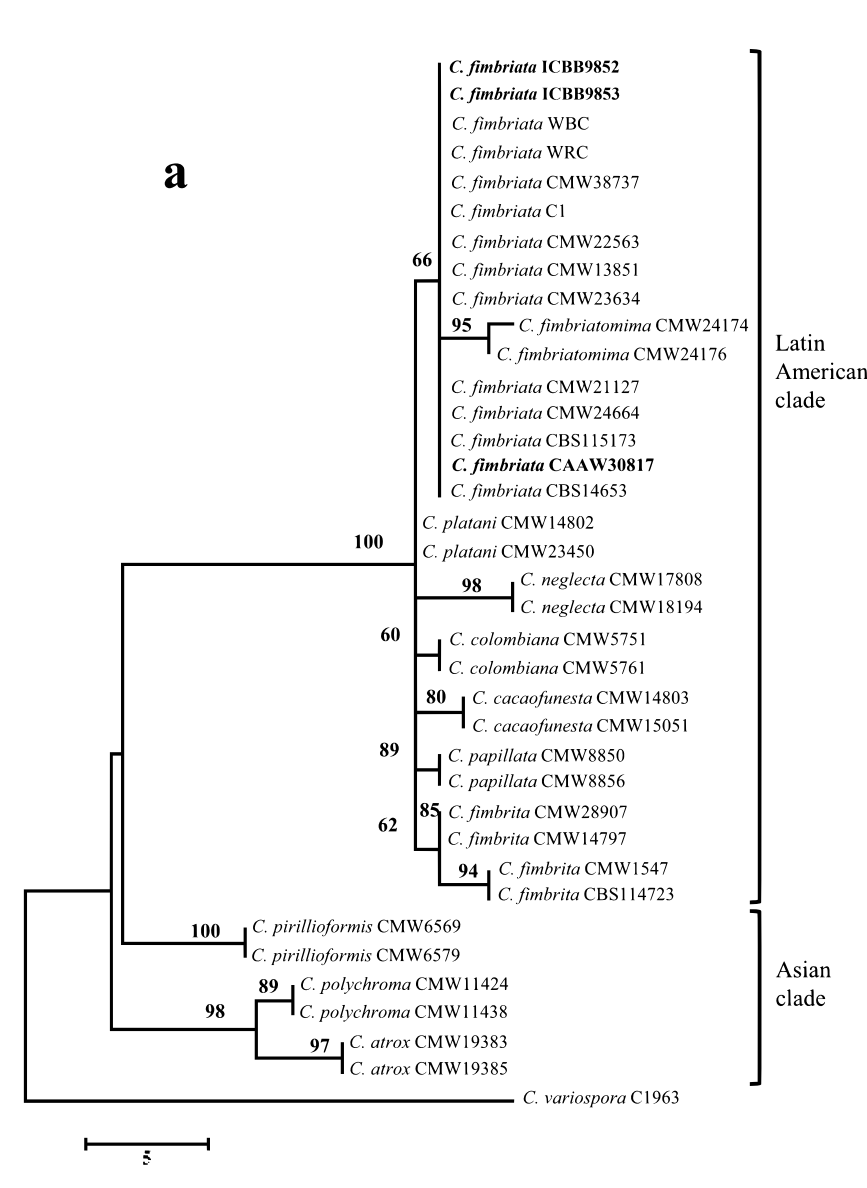

Fig. 3 Phylogenetic tree constructed by MEGA with Maximum Parsimony (MP) analysis by a $\beta$-tubulin sequences from Jackfruit tree in Indonesia (marked in bold) and other species in the Latin American diam.) taken from an actively growing colony of $C$. fimbriata on 2\% MEA (14 days) (Pratama et al. 2021) were placed in the wounds with the mycelium facing inwards. These were covered with Parafilm (Pechiney, Menasha, Wisconsin) to reduce contamination and desiccation. Ten plants of each tree species were inoculated with sterile MEA plugs to serve as controls (Fig. 4a). Fungal isolates were re-isolated and re-identified using morphological characteristics for confirmation of Koch's postulates. In pathogenicity tests, initial symptoms appeared two weeks post-inoculation as brown lesions at the inoculation site on the wood (Fig. 4b). Forty-five days after inoculation, plants exhibited wilt symptoms, lesions of wood discoloration extended to heartwood (Fig. 4c) and length of discolouration (downward + upward) was 17.88 until $34.74 \mathrm{~cm}$. When re-isolated, the fungus was phenotypically identical to the prior isolate of $C$. fimbriata (ICBB9852, ICBB9853, CAAW30817).

This is the first report of $C$. fimbriata causing wilt and dieback in Jackfruit in Indonesia and worldwide. The symptoms

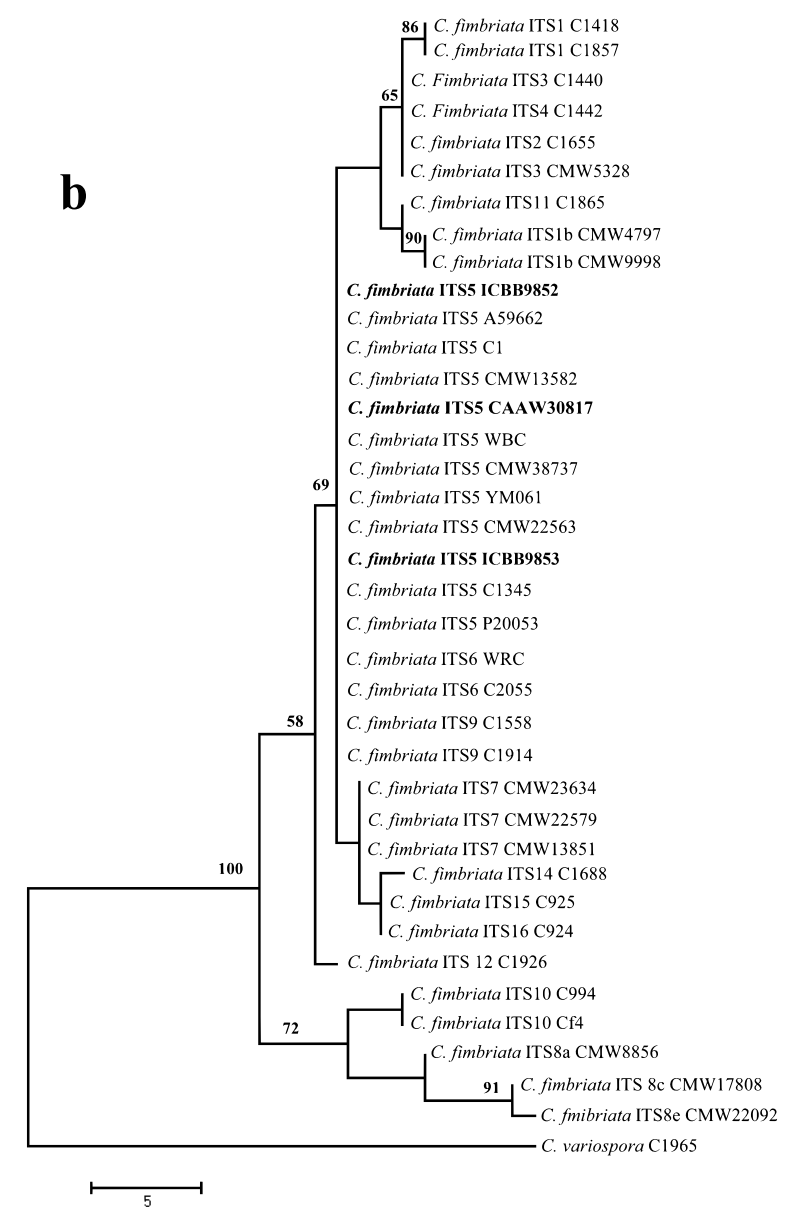

and Asian clade of the $C$. fimbriata species complex. b ITS sequences from Jackfruit tree in Indonesia (marked in bold) and genotypes (sequences) of the $C$. fimbriata sensu stricto 
Fig. 4 Response of Artocarpus heterophyllous seedlings 45 days after under-bark inoculation with mycelium of Ceratocystis. a total wilting of plant inoculated with ICBB9852 (I), CAAW30817 (II), ICBB9853 (III) and the healthy control seedling (IV); b yellow arrow indicates the point of inoculation and red arrow the lesion boundary; c The discoloured wood extended to the heartwood of the basal stem of the seedling

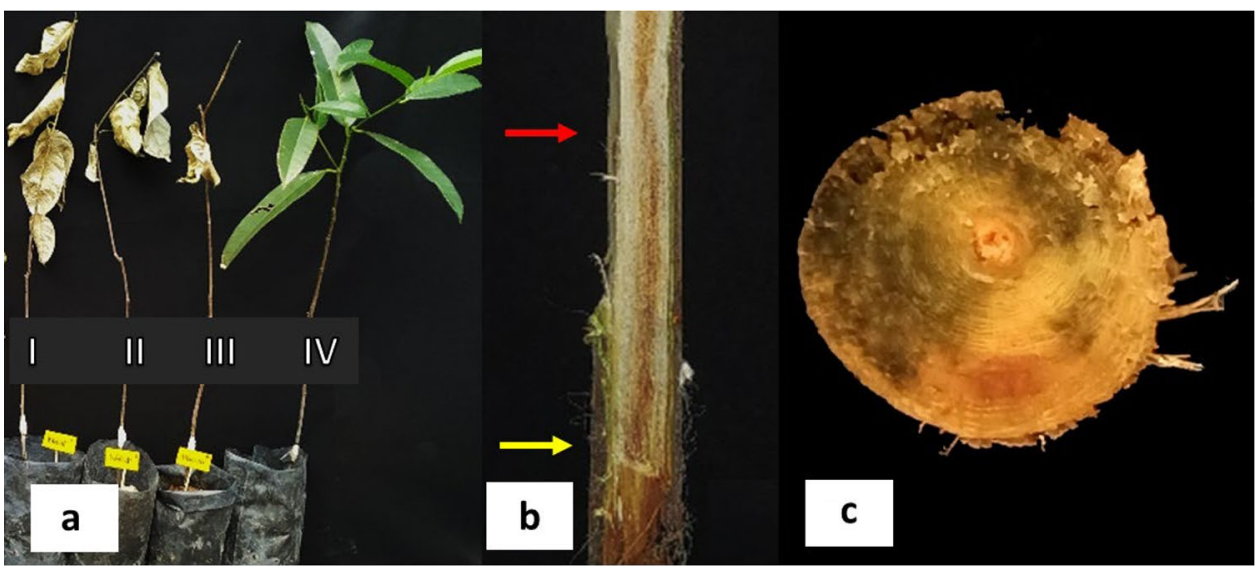

of $C$. fimbriata wilt disease in Jackfruit include cankers on stems, with the stems becoming chapped as though torn apart, fruit rot and progressive loss of the canopy resulting in tree death. Ceratocystis fimbriata is a serious wilt pathogen of jackfruit, as well as of A. mangium and A. crassicarpa in Indonesia (Tarigan et al. 2011), Lansium domesticum in Indonesia (Suwandi et al. 2021) and Pomegranate in China (Li et al. 2016). Ceratocystis fimbriata infections of native trees in these countries could potentially lead to devastation of important components of the natural biodiversity in Indonesia.

Acknowledgements This research was funded by PMDSU scholarship with budget year of 2019-2021 according to the Director of Research and Community Service, Directorate of Research and Community Service (DRPM), Directorate General for Research and Development, Ministry of Research, Technology, and Higher Education, Number: 068/SP2H/AMD/LT/DRPM/2020.

\section{References}

Barnes I, Fourie A, Wingfield MJ, Harrington TC, Mc-New DL, Sugiyama LS, Luiz BC, Heller WP, Keith LM (2018) New Ceratocystis species associated with rapid death of Metrosideros polymorpha in Hawai'i. Persoonia 40:154-181

Fourie A, Wingfield MJ, Wingfield BD, Barnes I (2015) Molecular markers delimit cryptic species in Ceratocystis sensu stricto. Mycol Prog 14:1020

Glass NL, Donaldson GC (1995) Development of primer sets designed for use with PCR to amplify conserved genes from filamentous Ascomycetes. Appl Environ Microbiol 61:1323-1330

Harrington TC, Kazmi MR, Al-Sadi AM, Ismail SI (2014) Intraspecific and intragenomic variability of ITS rDNA sequences reveals taxonomic problems in Ceratocystis fimbriata sensu stricto. Mycologia 106:224-242

Kumar S, Stecher G, Tamura K (2016) MEGA7: molecular evolutionary genetics analysis version 7.0 for bigger datasets. Mol Biol Evol 33:1870-1874
Li Q, Harrington TC, McNew D, Li J, Huang Q, Somasekhara YM, Alfenas AC (2016) Genetic bottlenecks for two populations of Ceratocystis fimbriata on sweet potato and pomegranate in China. Plant Dis 100:2266-2274

Moller WJ, DeVay JE (1968) Carrot as a species-selective isolation medium for Ceratocystis fimbriata. Phytopathology 58:123-124

O'Gara E, McComb JA, Colquhoun IL, Hardy GSJ (1997) The infection of non-wounded and wounded periderm tissue at the lower stem of Eucalyptus marginata by zoospores of Phytophthora cinnamomi, in a rehabilitated bauxite mine. Australas Plant Pathol 26:135-141

Oliveira LSS, Harrington TC, Ferreira MA, Damacena MB, Al-Sadi AM, Alfenas A-M (2015) Species or genotypes? Reassessment of four recently described species of the Ceratocystis wilt pathogen, Ceratocystis fimbriata, on Mangifera indica. Phytopathology 105:1229-1244

Paul CN, Nam SS, Kachroo A, Kim HY, Yang JW (2018) Characterization and pathogenicity of sweet potato (Ipomoea batatas) black rot caused by Ceratocystis fimbriata in Korea. Eur J Plant Pathol 152:7-8

Pratama R, Muslim A, Suwandi S, Damiri N, Soleha S (2021) First report of bullet wood (Mimusops elengi) sudden decline disease caused by Ceratocystis manginecans in Indonesia. Biodiversitas 22:2636-2645

Ranasinghe R, Maduwanthi S, Marapana R (2019) Nutritional and health benefits of jackfruit (Artocarpus heterophyllus Lam.): a review. Int J Food Sci 2019:1-12

Suwandi S, Irsan C, Hamidson H, Umayah A, Asriyani KD (2021) Identification and characterization of Ceratocystis fimbriata causing lethal wilt on the Lansium tree in Indonesia. Plant Pathol J 37:124-136

Tarigan M, Roux J, Van Wyk M, Tjahjono B, Wingfield MJ (2011) A new wilt and die-back disease of Acacia mangium associated with Ceratocystis manginecans and C. acaciivora sp. nov. in Indonesia. S Afr J Bot 77:292-304

White TJ, Bruns T, Lee S, Taylor J (1990) Amplification and direct sequencing of fungal ribosomal RNA genes for phylogenetics. In: Innis MA, Gelfand DH, Sninsky JJ, White TJ (eds) PCR protocols: a sequencing guide to methods and applications. Academic Press, San Diego, pp 315-322 